\title{
Caribbean acroporid coral hybrids are viable across life history stages
}

\author{
Nicole D. Fogarty* \\ Department of Biological Science, Florida State University, Tallahassee, Florida 32306-4295, USA \\ Present address: Smithsonian Marine Station, 701 Seaway Drive, Fort Pierce, Florida 34949, USA
}

\begin{abstract}
The Caribbean corals, Acropora palmata (elkhorn) and A. cervicornis (staghorn), are abundant in fossil records but recent disease outbreaks have led to unprecedented losses. Fused staghorn coral, A. prolifera, is an F1 hybrid with an intermediate morphology to the parental species. The hybrid is absent in the fossil record and has generally been documented as rarer than the parental species. Currently, however, hybrid abundance varies across geographic locations with some sites having equivalent or higher hybrid densities than at least one of the parental species. This apparent change in hybrid abundance may be a result of increased absolute hybrid abundance (i.e. hybrid embryo formation), increased relative abundance from increased asexual reproduction (i.e. fragmentation), or hybrids recently suffering less mortality than the parental species (i.e. hybrids lack the postzygotic barrier of inviability). Other studies have shown that prezygotic barriers are weak and many sampled hybrids have unique genotypes suggesting multiple distinct hybridization events. Here, postzygotic barriers of intrinsic and extrinsic inviability were examined across life history stages. Hybrids were not found to be inferior to the parental species at any examined life history stage, and in a few cases hybrid viability exceeded the parental species. Current evidence of weak reproductive isolation, an increase in the hybrid's relative abundance, and hybrid expansion into reef zones typically occupied by the parental species suggest that recent ecological changes in this system (i.e. dramatic declines in the parental species coupled with changes in the environment) may be affecting the frequency of hybridization.
\end{abstract}

KEY WORDS: Reproductive isolation $\cdot$ Acropora $\cdot$ Density dependence $\cdot$ Hybridization

\section{INTRODUCTION}

According to the biological species concept (BSC), if prezygotic barriers are weak and hybrid embryos form, postzygotic barriers (i.e. hybrid sterility and inviability) will reduce hybrid fitness and decrease the probability of introgression (i.e. gene flow across species boundaries) (Dobzhansky 1937, Mayr 1963, Coyne \& Orr 2004). If pre- and postzygotic barriers are lacking and selection favors hybridization, then hybrids may demonstrate greater fitness (i.e. hybrid vigor) than the parental species (Arnold 1997, 2006). Hybrid vigor can be the result of the combination of the best traits from each parent or associative over- dominance where heterozygotes have higher fitness than homozygotes (Crow 1948). Because heterozygosity is highest in the first generation hybrids (F1), superior fitness may be restricted to the F1 hybrid generation. Subsequent generations (i.e. backcross, F2, F3, etc.) may experience hybrid breakdown due to their reduced fitness compared to the parental species (Dobzhansky 1970, Coyne \& Orr 2004). Yet if later generation hybrid fitness is high, a stable hybrid lineage may form through hybrids occupying novel habitats or hybrids mating with one or both parental species allowing for introgression (Arnold 1997, 2006 Rhymer \& Simberloff 1996). Introgressive hybridization can lead to a variety of different outcomes, from 
the exchange of novel alleles that benefit the recipient species, to the loss of biodiversity through the genetic swamping of one or both parental species (Rhymer \& Simberloff 1996, Rieseberg 1997, Levin et al. 1996, Arnold 2006). These outcomes will likely depend upon the strength of reproductive isolating barriers and the frequency of introgression.

Botanists have long understood the evolutionary importance of introgressive hybridization (Anderson 1949, Stebbins 1959, Grant 1981), but it has only recently been documented across a variety of animal taxa (Arnold 1997, 2006, Dowling \& Secor 1997, Willis et al. 2006, Arnold \& Fogarty 2009). Corals share many life history characteristics with plants, e.g. sessile as adults, broadcast gametes, lack mating behavior, commonly hermaphroditic, and effectively use asexual propagation, and therefore are likely to undergo similar evolutionary processes (Willis et al. 2006). Molecular data suggest that the Indo-Pacific acroporids, like plants, have undergone reticulate evolution where species fuse and separate over time through repeated hybridization and introgression (Veron 1995, Hatta et al. 1999, van Oppen et al. 2000, Willis et al. 2006). Other coral characteristics, such as their longevity in the fossil record, ability to hybridize, extensive diversity, biogeographic patterns, mode of reproduction, and long distant dispersal, give further evidence that reticulate evolution has occurred (Veron 1995, Odorico \& Miller 1997, Hatta et al. 1999, Willis et al. 2006, reviewed in Arnold \& Fogarty 2009). However, the complexity of the IndoPacific acroporid system with more than 100 extant species (Wallace 1999) makes studying hybridization challenging.

In the Caribbean acroporids, hybridization dynamics are easier to untangle because there are only 3 taxa Acropora palmata, A. cervicornis, and A. prolifera (Wallace 1999, van Oppen et al. 2000, Vollmer \& Palumbi 2002). Molecular data demonstrate that sampled $A$. prolifera colonies, recognized by their intermediate morphology and marginal or intermediate habitat preference, are heterozygous at 3 species diagnostic nuclear loci (i.e. PaxC, miniCollagen, calmodulin), a result consistent with these colonies being first generation hybrids (van Oppen et al. 2000, Vollmer \& Palumbi 2002). Although F2 hybrids were not found, evidence of introgression suggests hybrids mate with at least A. cervicornis. Van Oppen et al. (2000) found that 2 of the 6 alleles examined at the nuclear PaxC intron were at high frequencies in $A$. palmata and low frequencies in $A$. cervicornis, while a different allele dominated $A$. cervicornis. This suggests that unidirectional low frequency gene flow occurs from A. palmata to A. cervicornis. Further molecular studies discovered that unidirectional gene flow varies among loci and across geographic sites (Vollmer \& Palumbi 2002, 2007, Hemond \& Vollmer 2010). For example, the percent of the total A. cervicornis sequences found to be introgressed with $A$. palmata haplotypes varied across the Caribbean, e.g. $0 \%$ in Belize, $27 \%$ in Puerto Rico, $60 \%$ in Panama, and $68 \%$ in the Upper Florida Keys (Vollmer \& Palumbi 2007, Hemond \& Vollmer 2010). The lack of F2 hybrids and differential introgression across 4 sampled loci led Vollmer \& Palumbi (2002) to speculate that postzygotic selection limits unidirectional introgression into $A$. cervicornis, albeit at different strengths across loci. However, postzygotic mechanisms have never been examined in this system, and recent drastic changes in the ecology of Caribbean acroporids may have affected the strength of this reproductive isolating mechanism.

Acropora palmata and A. cervicornis were the dominant shallow-water corals in the Caribbean for millions of years (McNeill et al. 1997, Budd \& Johnson 1999). Since the early 1980s, these parental species have experienced declines up to $97 \%$ and are now listed as threatened under the US Endangered Species Act (Aronson \& Precht 2001, Bruckner 2002, Precht et al. 2002, Miller et al. 2002, Acropora Biological Review Team 2005, Hogarth 2006). The cause of mortality is primarily attributed to disease outbreaks (Aronson \& Precht 2001, Bruckner 2002, Precht et al. 2002); yet physical breakage, predation, and coral bleaching are among the other factors contributing to decline (Knowlton et al. 1990, Bruckner 2002, Miller et al. 2002, Acropora Biological Review Team 2005, Williams \& Miller 2005).

Hybrids are absent from the fossil record (Budd et al. 1994) and are documented as being rarer than the parental species at most sites throughout the Caribbean (Goreau 1959, Lang et al. 1998, Cortes 2003, Willis et al. 2006), with occasional pockets of high abundance occurring in marginal, nonparental habitats (Adey et al. 1977, Goreau 1959, Cairns 1982, Rutzler \& MacIntyre 1982). Now it appears that the relative abundance of the 3 taxa and the habitat in which hybrids occur may be changing. Hybrid populations currently vary in abundance, but there is evidence (i.e. Dry Tortugas, FL; Wheaton et al. 2010) and anecdotal observations that sites throughout the Caribbean have equivalent or higher relative abundance than one or both of the parental species. In addition, the location of hybrids is not restricted to marginal habitats, but is observed across all reef zones including areas typically dominated by the 
parental species (Fogarty 2010). The apparent change in relative hybrid abundance may be a result of increased hybrid embryo formation, increased asexual fragmentation or because hybrids are more viable than the parental species and have suffered less mortality in recent decades.

A study examining prezygotic barriers through the frequency of hybrid embryo formation in the presence and absence of sperm competition found species-specific differences in gametic incompatibilities (Fogarty et al. in press). Acropora palmata eggs are relatively resistant to hybridization especially when conspecific sperm are available to outcompete heterospecific sperm. Acropora cervicornis eggs demonstrate no evidence for gametic incompatibility (Fogarty et al. in press). Furthermore, molecular data suggest that at many sites across the Caribbean, hybrid populations are genotypically diverse (i.e. composed of multiple distinct genotypes); therefore, asexual fragmentation cannot solely explain high hybrid abundances (Fogarty 2010). These studies suggest that prezygotic barriers are weak, but the strength of postzygotic barriers (i.e. hybrid sterility, hybrid inviability, and hybrid breakdown) remain unclear. Based on molecular evidence of unidirectional introgression (Vollmer \& Palumbi 2002, 2007, Hemond \& Vollmer 2010), hybrids mate with A. cervicornis to form a backcross generation providing a conduit for genes to flow from A. palmata to A. cervicornis. Thus hybrid sterility can be ruled out, but the other two potential postzygotic barriers of hybrid inviability and breakdown have yet to be explored. Hybrid inviability can be divided into intrinsic (i.e. developmental problems independent from environment) or extrinsic (i.e. develop normally, but demonstrate lower fitness because they fail to find an appropriate ecological niche). Hybrid breakdown is a postzygotic barrier specific to later generation hybrids, where the offspring of hybrids do not reach sexual maturity or are sterile (Coyne \& Orr 2004).

The relative contribution of isolating barriers may differ; therefore, multiple postzygotic mechanisms across life history stages need to be assessed in order to determine the collective strength of reproductive isolation (Ramsey et al. 2003, Mendelson et al. 2007). Caribbean acroporids have a complex life cycle which includes external fertilization and a pelagic larval stage. Acroporids reach sexual maturity in 4 to 8 yr (Wallace 1985) and are simultaneous hermaphrodites that broadcast bundles containing eggs and sperm typically 2 to $6 \mathrm{~d}$ after the full moon in July, August, and September (Szmant 1986, VargasAngel 2003, Fogarty et al. in press). Fertilization occurs at the surface and the embryos develop into planula larvae. After $4 \mathrm{~d}$, the larvae become competent, having the ability to settle and metamorphose (Ritson-Williams et al. 2010). Habitat selection and settlement is a crucial life history stage for sessile organisms that typically cannot relocate from suboptimal habitats once recruitment has occurred (for a rare exception see polyp bailout; Sammarco 1982). Coral larvae have been found to be attracted to substrates with certain species of crustose coralline algae (CCA) (Carlon \& Olson 1993, Morse et al. 1988, 1994, Morse \& Morse 1991, Morse et al. 1994, Heyward \& Negri 1999, Golbuu \& Richmond 2007, Ritson-Williams et al. 2010) and biofilms (Harrigan 1972, Baird \& Morse 2004, Webster et al. 2004, Golbuu \& Richmond 2007). Because newly settled corals are particularly vulnerable to overgrowth by algae and sessile invertebrates, predation, disturbance, and sedimentation (Rylaarsdam, 1983, RitsonWilliams et al. 2009), the early post-settlement period is considered a potential survival bottleneck with often extremely high mortality rates (Vermeij \& Sandin 2008).

Mortality in adult acroporids is attributed to numerous factors (i.e. disease, predation, parasitism, overgrowth, and coral paling or bleaching; Bruckner 2002, Williams et al. 2006), and here these factors are collectively called afflictions. White-band disease affects all Caribbean acroporids and is the primary disease that has led to the loss of Acropora palmata and A. cervicornis (Aronson \& Precht 2001, Precht et al. 2002). Other diseases, such as white pox, which only affects $A$. palmata, and rapid tissue loss have also contributed to acroporid mortality (Bruckner 2002, Patterson et al. 2002, Williams \& Miller 2005, Williams et al. 2006). Fish (i.e. damselfish, parrotfish), corallivorous snails (Coralliophila abbreviata and C. caribbaea), and fireworms (Hermodice carunculata) are the primary predators that feed on Caribbean acroporids (Bruckner 2002, Williams et al. 2006). The most frequent parasites are polychaete worms and excavating sponges that bore into the coral skeleton and can lead to bioerosion (Risk et al. 1995, Williams et al. 2006). Acroporids are overgrown mostly by macroalgae or encrusting sponges (Bruckner 2002, Williams et al. 2006, Fogarty pers. obs.). Finally, when the symbiotic dinoflagellate, called zooxanthellae, are at low abundance or absent, the corals appear paled or white (i.e. coral bleaching) because the coral skeleton is visible through the translucent tissue (Glynn 1993, Brown 1997). Coral bleaching occurs when the zooxanthellae leave the gastrodermal cells of the coral during times of stress such as extreme fluctuations in 
temperature or salinity, or elevated levels of sedimentation or ultraviolet radiation. Bleached corals suffer from reduced growth, fecundity, and calcification rates; prolonged bleaching episodes may result in coral morality (Szmant \& Gassman 1990, Tudhope et al. 1992, Glynn 1993, Wilkinson 2000, Goreau et al. 2000). The prevalence of these afflictions can indicate the viability of each taxon.

Here I examine the barrier of intrinsic postzygotic inviability by comparing the survival and health of hybrids to the parental species at various life history stages: (1) larval, (2) settlement, (3) post-settlement, and (4) adult. To assess the viability of the adult stage, I conducted field surveys and quantified the frequency of afflictions (i.e. disease, parasitism, predation, coral bleaching, and being overgrown by other organisms) that have contributed to the decline of these species. In addition, I explored extrinsic ecological inviability through habitat preference and reciprocal transplant experiments.

\section{MATERIALS AND METHODS}

\section{Hybrid identification}

Colonies with an intermediate morphology between Acropora palmata and A. cervicornis were originally named $A$. prolifera (Lamarck 1816) but were recently determined to be F1 hybrids (van Oppen et al. 2000, Vollmer \& Palumbi 2002). In this study, larvae used for larval viability, settlement choice experiments, and postsettlement survival were created in the laboratory by crossing gametes from A. palmata and A. cervicornis, and therefore are known F1 hybrids. Molecular analysis was not conducted on all adult colonies used in the affliction assessments and reciprocal transplants; consequently, it is not clear if these colonies are first generation or later generation hybrids. Hereafter, I collectively refer to these colonies as hybrids because they are not a reproductively isolated species, as suggested by the species name $A$. prolifera. These colonies might not be heterozygous at each locus as previous molecular data suggest (van Oppen et al. 2000, Vollmer \& Palumbi 2002); nevertheless, they have a mix of alleles (i.e. hybrid) from the 2 parental species.

\section{Habitat, density, and biomass}

Sites (East Rocks, Antigua; Flat Key, St. Thomas; Sea Aquarium and Director's Bay, Curacao; Carrie
Bow Cay and Caye Caulker, Belize) were selected based on anecdotal observations of acroporid hybrids; however, the abundance of the 3 taxa or the environment in which they lived was not known prior to the site visit. At each site, a transect line (30 to $60 \mathrm{~m}$ ) was haphazardly extended through the acroporid population and used for density (no. colonies $\mathrm{m}^{-1}$ ), biomass (mean colony volume), and condition assessments (see 'Adult afflictions field surveys' section below). Acroporid density was quantified by counting all individuals within $1 \mathrm{~m}$ on each side of the transect line and dividing by the total area surveyed. Volumetric measurements of live tissue (length, width, and height to the closest $5 \mathrm{~cm}$ ) were conducted for each colony. Since the number of colonies assessed differed between taxa and sites, 10 colonies of each taxon were randomly selected from each site and used for mean biomass comparisons. For each site, a 1-way ANOVA and Tukey's HSD were conducted to determine differences in biomass among taxa. A 1-way ANOVA was used to determine if hybrid density differed among taxa across all 6 sites.

Wave energy designations (high, moderate, or low) were based on my qualitative observations. Acroporid sites in the backreef or lagoonal environments were categorized as low, sites with occasional wave action as moderate, and sites with consistent waves and high surge were considered high wave energy. Adult affliction assessments were conducted at all sites, reciprocal transplants were conducted in Curacao, and larvae and settlement studies were conducted in south Carrie Bow Cay, Belize (see Table 1).

\section{Adult afflictions field surveys}

Belt transects examining the number of colonies with afflictions (i.e. predation, disease, paling or bleaching, parasitism, and being overgrown by another organism) and the severity of each affliction were conducted over a $4 \mathrm{yr}$ period. Acroporid colonies within $1 \mathrm{~m}$ on each side of a transect line were assessed for evidence of afflictions and the percentage of the colony showing signs of each affliction was recorded as one of 6 categories $(0 \%, 1-10 \%$, $11-25 \%, 26-50 \%, 51-75 \%, 76-100 \%)$. The 6 categories were assigned a categorical number (i.e. 0 to 5) in a Kruskal-Wallis ANOVA by ranks to statistically determine differences in the severity of each affliction on colonies across taxa. A chi-squared test was use to determine differences in the total number of afflicted colonies across all sites and years. Data were also pooled and used in a chi-squared test to 
explore differences across taxa regardless of site and year. To visually demonstrate patterns in affliction severity across taxa, multidimensional scaling (MDS) was used. Because the majority of the colonies did not show evidence of more than one affliction and some colonies showed no evidence of any afflictions, zeroes were prolific throughout these data and therefore were deleted prior to conducting the MDS.

\section{Larval survival}

In Belize, gamete bundles were collected in the field during natural spawning events and separated and crossed in the laboratory (Fogarty et al. in press). Larvae ( 50) from crosses between known egg and sperm donors were placed in Petri dishes with filtered seawater (Whatman $0.45 \mu \mathrm{m}$ ). Each morning any decaying larvae were removed, $75 \%$ of the seawater was exchanged, and healthy larvae were counted. During the first year of the study, some of the dishes were contaminated by bacteria which led to the death of the larvae; therefore, these trials were excluded from the analysis. To prevent bacterial contamination in subsequent larval survival experiments, the antibiotic amoxicillin was added to the filtered seawater at a concentration of $0.25 \mathrm{~g} \mathrm{l}^{-1}$. Mean larval survival per trial was compared among taxa using a 1-way repeated measures ANOVA with taxon as the main effect and the arcsine-transformed proportion of larvae surviving as the dependent variable. The number of crosses was 50,68, and 24 and the number of larvae was 3128, 2624, and 1336 for Acropora palmata, hybrids, and A. cervicornis, respectively.

\section{Substrate selection and post-settlement survival}

In Belize, hybrids live in shallow $(<1 \mathrm{~m})$, high wave energy environments, while most of Acropora palmata and A. cervicornis colonies co-occur in a slightly deeper habitat (2 to $4 \mathrm{~m}$ ). A settlement study was conducted to determine which habitat acroporid larvae prefer. A hole (diameter: $7 \mathrm{~mm}$ ) was drilled in the center of each porcelain square tile $(48 \mathrm{~mm}$ in length). A rope was thread through the tiles and a $0.5 \mathrm{~cm}$ PVC spacer was placed between each tile. The ropes were secured to the substrate at depths of $0.75 \mathrm{~m}$ (hybrid zone) and $3 \mathrm{~m}$ (parental zone). Tiles were conditioned for $13 \mathrm{mo}$ and then brought into the laboratory for preparation. Twenty-seven tiles were haphazardly selected from each habitat. Inverte- brates and macroalgae were scraped off the tiles in order to increase the available substrate for coral settlement, to aid in visually detecting newly settled corals, and to reduce competition with the newly settled corals during the postsettlement survival experiments. Although the removal of potential competitors may not reflect the natural composition of the substrate, it allows the testing of intrinsic viability among taxa without the potential bias of competitors that might influence survival.

The substrate selection experiment was implemented $4 \mathrm{~d}$ after fertilization. Two tiles, one from each zone, were placed in a $400 \mathrm{ml}$ plastic tri-pour beaker where the bottom had been replaced with 100 to $180 \mu \mathrm{m}$ nitex mesh. Tiles were leaning against the side of the beaker at an $\sim 45^{\circ}$ angle. This beaker was placed in an $800 \mathrm{ml}$ beaker with seawater. From batch cultures of Acropora cervicornis, A. palmata, or the hybrid (from $A$. cervicornis eggs), 18 larvae each were added to the beaker and given a choice of 2 tiles. There were 9 replicate beakers for each taxon. Water was changed daily. Eight days after fertilization, all tile surfaces were carefully examined for newly settled corals using a dissecting microscope. The newly settled corals were mapped by placing a clear plastic grid over the tile and recording the quadrat in which the coral had settled. For substrate selection, a 2-way ANOVA was used with the total settled corals as the dependent variable and taxa and the zone in which the tiles were conditioned as the main effects.

Since the proportion of CCA covering the tiles may affect settlement, the amount of CCA on a subset of tiles was calculated using ImageJ software. Six tiles for each taxon were haphazardly selected and both sides of the tiles were photographed. A $t$-test was used to determine if the mean proportion of CCA covering a tile differed between the zones in which the tiles were conditioned. An ANCOVA was used to determine if the proportion of CCA influenced settlement on these tiles. The dependent variable was the number of settled corals, the arcsine-transformed proportion of CCA covering the tiles was the covariate, and the taxa and zone in which the tiles were conditioned were the main effects.

Settlement tiles that were conditioned in the parental zone and where at least 2 corals settled were used in an experiment to compare the post-settlement survival among acroporid taxa. Using a nylon screw and wing nut, the tiles were secured to a flattened wire mesh cylinder (length $\times$ width $\times$ height $=10 \times 8 \times$ $5 \mathrm{~cm}$ ) with open ends. The open-ended cages were tagged and secured to the substrate in the parental 
zone with stainless steel fence staples and masonry nails. Six tiles with a total of 28 Acropora palmata recruits, 6 tiles with 23 hybrid recruits, and 5 tiles with 14 A. cervicornis recruits were de-ployed in the parental zone. Because very few A. cervicornis larvae settled on the hybrid tiles, a reciprocal post-settlement survival experiment with all taxa was not possible. However, to determine hybrid survival across both zones, tiles that had been conditioned in the hybrid zone and had at least 1 hybrid recruit were returned to the hybrid zone. After $6 \mathrm{wk}$ all tiles were collected and carefully examined for coral survivors. Tiles that had survivors were returned to the same habitat and examined $1 \mathrm{yr}$ later. The difference in the proportion of newly settled corals surviving 6 wk was examined among taxa using a 1-way ANOVA. A $t$-test was used to determine if hybrid recruit survival was different in the parental versus hybrid zone.

\section{Reciprocal transplants}

Reciprocal transplants compared the viability of hybrids in all acroporid environments to decipher if hybrid inviability is extrinsic (i.e. exogenous selection against hybrids; Levin \& Schmidt 1985, Wang et al. 1997). Reciprocal transplants were performed in Curacao where taxa typically occupy 3 zones: shallow, hybrid zone $(1.5 \mathrm{~m})$, intermediate Acropora palmata zone $(3 \mathrm{~m})$, and deep A. cervicornis zone $(7 \mathrm{~m})$, with some overlap between hybrid and $A$. palmata colonies. Blocks of cement with epoxied acroporid fragments were used as experimental units. Cement was poured into 9 plastic bins (length $\times$ width $\times$ height $=35 \times 25 \times 20 \mathrm{~cm}$ ) and 6 narrow and 3 wide PVC pipes $(2.5$ and $5 \mathrm{~cm}$ diameter, respectively) were haphazardly placed in the wet cement in a $3 \times 3$ matrix where half of the $4 \mathrm{~cm}$ long PVC pipe protruded from the cement. Six colonies of each taxon were selected haphazardly to serve as the donor colonies. Three $10 \mathrm{~cm}$ fragments were clipped from each colony and epoxied (using nontoxic Aquastick by Two Little Fishes) to a PVC pipe that was embedded in concrete. One fragment from each donor colony was placed at each depth. Because of the different acroporid morphologies, hybrid and $A$. cervicornis fragments were epoxied in the $2.5 \mathrm{~cm}$ diameter PVC, and A. palmata fragments were epoxied in the $5 \mathrm{~cm}$ diameter $\mathrm{PVC}_{\text {; }}$ otherwise the location within the matrix where the fragment was epoxied was selected randomly. In each bin, there were 2 fragments of each taxon collected from independent colonies for a total of 6 fragments per bin, leaving 3
PVC pipes empty. Fragment survival was monitored by photographing the bins at 2, 6, and $12 \mathrm{mo}$, and growth rate was manually measured initially and at 12 mo. Because survival was low in the shallow and intermediate habitats, the overall survival across habitats was pooled and analyzed using a binomial analysis. The height of transplants was examined after 1 yr using a 2-way ANOVA with taxa and transplant zone as the main effects and the linear growth measurement as the dependent variable.

\section{RESULTS}

\section{Habitat, density, and biomass}

The location of the hybrid in relation to the parental species differed among sites; however, at all sites some overlap occurred between the hybrid and at least one of the parental species. At Flat Key, St. Thomas, and East Rocks, Antigua, hybrids were found co-occurring with Acropora cervicornis, while hybrids primarily overlapped with $A$. palmata at the Sea Aquarium, Curacao, and north Caye Caulker, Belize. A greater separation was observed between the hybrids and the parental species at Director's Bay, Curacao, and south Carrie Bow Cay, Belize.

Hybrid and parental species density (no. colonies $\mathrm{m}^{-1}$ ) and the mean colony biomass (based on volumetric measurements) varied across sites, with no apparent correlation to wave environment in which they live. Typically, hybrids and Acropora palmata were found in moderate to high wave energy habitats while A. cervicornis mostly existed in low to medium wave energy environments (Table 1). Across the 6 geographic sites, the mean acroporid density did not significantly differ among taxa (MS $=0.016, \mathrm{df}=2$, $F=0.321, \mathrm{p}=0.730$ ). Hybrid density was equivalent or exceeded at least one of the parental species at 4 out of 6 sites (Director's Bay and Carrie Bow Cay sites are exceptions). Hybrids had equivalent biomass to both parental species at East Rocks (ANOVA, p $=0.14$; Table 1) and had equivalent biomass to $A$. cervicornis at south Carrie Bow Cay and north Caye Caulker (Tukey's HSD, $p=0.08 ; p=0.99$ ), but had less biomass than both parental species at Flat Key, Sea Aquarium, and Director's Bay (Tukey's HSD, p < 0.05).

\section{Adult afflictions}

Across multiple years, 3 sites were sampled: Carrie Bow Cay, Sea Aquarium, and Director's Bay. With the 
Table 1. Acropora palmata, A. cervicornis, and hybrid. Density and biomass of Caribbean acroporid taxa, the wave environment $(\mathrm{H}=$ high; $\mathrm{M}=$ moderate $\mathrm{L}=$ low $)$ in which they live, and the experiment or assessment conducted at each site $(\mathrm{LS}=$ larval survival; $\mathrm{SP}=$ substrate preference; $\mathrm{PS}=$ post-settlement survival; $\mathrm{AA}=$ adult affliction; $\mathrm{RT}=$ reciprocal transplant). Different letters in the Tukey's column indicate significant $(\mathrm{p}<0.05)$ differences in the taxa within a site

\begin{tabular}{|c|c|c|c|c|c|c|c|c|c|}
\hline \multirow[t]{2}{*}{ Locality } & \multirow[t]{2}{*}{ Site } & \multirow[t]{2}{*}{ Taxon } & \multirow{2}{*}{$\begin{array}{l}\text { Area } \\
\left(\mathrm{m}^{2}\right)\end{array}$} & \multicolumn{2}{|c|}{ —Colonies -} & \multicolumn{2}{|c|}{$\longrightarrow$ Biomass -} & \multirow{2}{*}{$\begin{array}{l}\text { Wave } \\
\text { action }\end{array}$} & \multirow[t]{2}{*}{ Test } \\
\hline & & & & No. & $\begin{array}{l}\text { Density } \\
\left(\text { no. } \mathrm{m}^{-1}\right)\end{array}$ & $\begin{array}{l}\text { Mean vol. } \\
\left(\mathrm{cm}^{3}\right)\end{array}$ & Tukey's & & \\
\hline \multirow[t]{3}{*}{ Antigua } & \multirow[t]{3}{*}{ East Rocks } & A. palmata & 360 & 19 & 0.05 & $1.4 \times 10^{6}$ & $\mathrm{a}$ & M & AA \\
\hline & & Hybrid & 360 & 18 & 0.05 & $9.7 \times 10^{7}$ & $\mathrm{a}$ & L & AA \\
\hline & & A. cervicornis & 360 & 16 & 0.04 & $4.0 \times 10^{5}$ & $\mathrm{a}$ & $\mathrm{L}$ & AA \\
\hline \multirow[t]{3}{*}{ St. Thomas } & \multirow[t]{3}{*}{ Flat Key } & A. palmata & 36 & 29 & 0.81 & $2.8 \times 10^{5}$ & $\mathrm{a}$ & $\mathrm{H}$ & LS, SP, PS, AA \\
\hline & & Hybrid & 56 & 31 & 0.55 & $2.1 \times 10^{4}$ & $\mathrm{~b}$ & $\mathrm{H}$ & LS, SP, PS, AA \\
\hline & & A. cervicornis & 80 & 36 & 0.45 & $5.7 \times 10^{4}$ & C & M & LS, SP, PS, AA \\
\hline \multirow[t]{3}{*}{ Curacao } & \multirow[t]{3}{*}{ Sea Aquarium } & A. palmata & 60 & 14 & 0.23 & $1.0 \times 10^{6}$ & $\mathrm{a}$ & $\mathrm{H}$ & $\mathrm{AA}, \mathrm{RT}$ \\
\hline & & Hybrid & 3250 & 31 & 0.01 & $2.2 \times 10^{4}$ & $\mathrm{~b}$ & $\mathrm{H}$ & $\mathrm{AA}, \mathrm{RT}$ \\
\hline & & A. cervicornis & 1700 & 15 & 0.01 & $9.9 \times 10^{5}$ & a & $\mathrm{L}$ & $\mathrm{AA}, \mathrm{RT}$ \\
\hline \multirow[t]{3}{*}{ Curacao } & \multirow[t]{3}{*}{ Director's Bay } & A. palmata & 60 & 11 & 0.18 & $3.6 \times 10^{8}$ & $\mathrm{a}$ & M & AA \\
\hline & & Hybrid & 100 & 11 & 0.11 & $1.8 \times 10^{4}$ & $\mathrm{~b}$ & M & AA \\
\hline & & A. cervicornis & 60 & 20 & 0.33 & $5.6 \times 10^{8}$ & $\mathrm{a}$ & M & $\mathrm{AA}$ \\
\hline \multirow[t]{3}{*}{ Belize } & \multirow{3}{*}{$\begin{array}{l}\text { South Carrie } \\
\text { Bow Cay }\end{array}$} & A. palmata & 100 & 13 & 0.13 & $1.1 \times 10^{5}$ & $\mathrm{a}$ & M & LS, SP, PS, AA \\
\hline & & Hybrid & 9000 & 77 & 0.01 & $1.1 \times 10^{4}$ & $\mathrm{~b}$ & $\mathrm{H}$ & LS, SP, PS, AA \\
\hline & & A. cervicornis & 100 & 27 & 0.27 & $5.2 \times 10^{4}$ & $a b$ & M & $\mathrm{LS}, \mathrm{SP}, \mathrm{PS}, \mathrm{AA}$ \\
\hline \multirow[t]{3}{*}{ Belize } & \multirow{3}{*}{$\begin{array}{l}\text { North Caye } \\
\text { Caulker }\end{array}$} & A. palmata & 100 & 12 & 0.12 & $1.2 \times 10^{6}$ & $\mathrm{a}$ & $\mathrm{H}$ & AA \\
\hline & & Hybrid & 100 & 17 & 0.17 & $3.6 \times 10^{4}$ & $\mathrm{~b}$ & $\mathrm{H}$ & AA \\
\hline & & A. cervicornis & 100 & 14 & 0.14 & $6.4 \times 10^{4}$ & $\mathrm{~b}$ & $\mathrm{H}$ & AA \\
\hline
\end{tabular}

exception of parasitism, little interannual variation in the number of colonies affected by each affliction was observed. The prevalence of parasitism in Acropora palmata seemed particularly variable with significant difference seen between years for all 3 sites (for details see Fogarty 2010). Hybrids showed variation in the number of colonies with parasites and with predation scars at the Sea Aquarium site between 2006 and 2007 and between 2006 and 2009. For A. cervicornis, disease at Carrie Bow Cay was the only affliction that was significantly different between sampling years (for details see Fogarty 2010).

Data across years were pooled to explore site differences in the number of afflicted colonies of each taxon. Significant differences in the prevalence of each affliction were seen among sites and these differences varied among taxa (Table 2). For instance, Acropora palmata colonies had significant site differences for predation, paling or bleaching, and parasitism, while $A$. cervicornis differed in predation, disease, and paling or bleaching among sites. Disease, parasitism, and overgrowth were significantly different among sites in the hybrid (Table 2).

Overall patterns in the prevalence of afflictions among taxa were examined by pooling data across sites. There was a significant difference among taxa for all afflictions except bleaching (Fig. 1). Compared to the parental species, hybrids had equivalent or lower prevalence of each affliction with the exception of overgrowth (Fig. 1f). Acropora palmata colonies were primarily afflicted by predation and parasitism (Fig. 1C,e), and A. cervicornis colonies were mostly afflicted by disease and predation (Fig. 1b,c).

The severity (i.e. the proportion of the colony visibly affected by the affliction) of each affliction differed across sites and taxa, but to a lesser extent across years (see Fogarty 2010 for site specific data) and overall followed similar patterns as the affliction prevalence data (Figs. 1 \& 2). Acropora palmata was most severely afflicted by predation and parasitism, while disease and predation severely afflicted A. cervicornis. The hybrid was mostly affected by over-

Table 2. Acropora palmata, A. cervicornis, and hybrid. Chi-squared tests (p-values) comparing differences in the number of colonies affected by each affliction across sites in Antigua, Belize, Curacao, and St. Thomas.

Bold: statistically significant $(p<0.05)$ difference across sites

\begin{tabular}{|lrrrrc|}
\hline Taxon & Predation & Disease & Bleaching & Parasitism & Overgrowth \\
\hline A. palmata & $\mathbf{0 . 0 0 8}$ & 0.068 & $\mathbf{0 . 0 2 2}$ & $<\mathbf{0 . 0 0 1}$ & 0.568 \\
Hybrid & 0.198 & $\mathbf{0 . 0 0 1}$ & 0.212 & $<\mathbf{0 . 0 0 1}$ & $\mathbf{0 . 0 0 8}$ \\
A. cervicornis & $<\mathbf{0 . 0 0 1}$ & $<\mathbf{0 . 0 0 1}$ & $\mathbf{0 . 0 1 6}$ & 0.616 & 0.145 \\
\hline
\end{tabular}



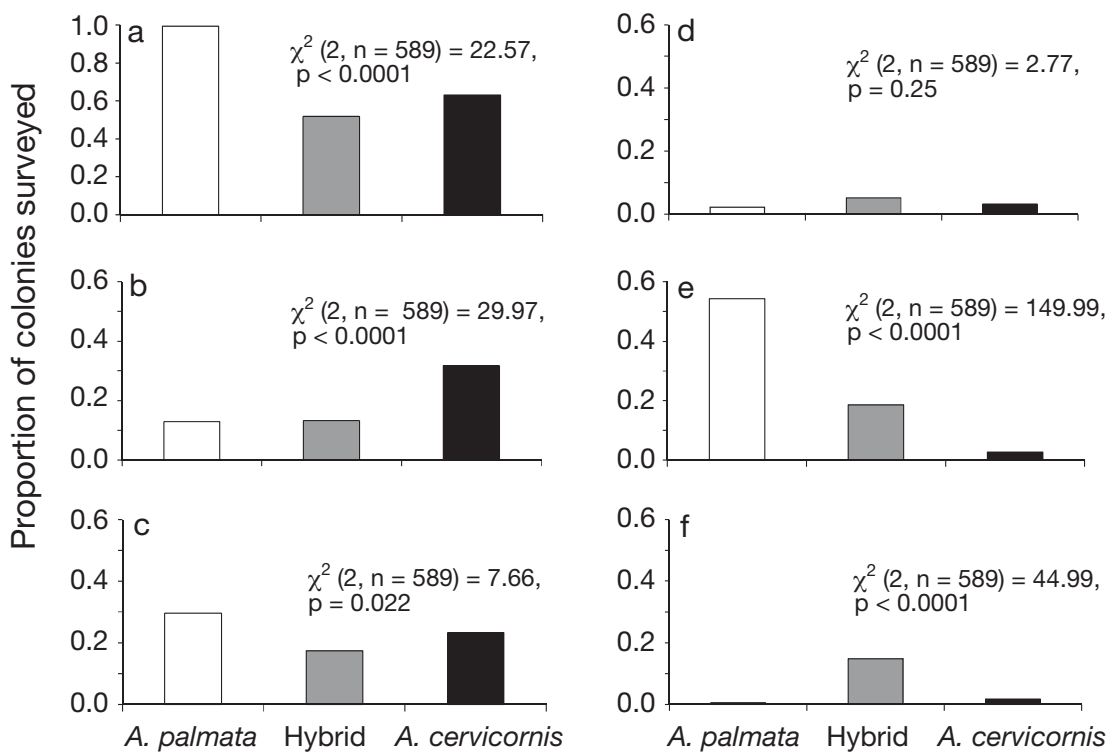

Fig. 1. Acropora palmata, A. cervicornis, and hybrid. Comparison across taxa of the proportion of colonies afflicted by (a) all afflictions, (b) disease, (c) predation, (d) paling or bleaching, (e) parasitism, and (f) being overgrown by other organisms

growth of other organisms (Fig. 2). The KruskalWallis test revealed that paling/bleaching was the only affliction that did not significantly differ among taxa (Table 3).

\section{Larval survival and settlement}

Little difference was observed in larval survival and substrate selection among the 3 taxa, but the number of larvae that settled differed between the parental species. Larval survival decreased over the first $5 \mathrm{~d}$ after fertilization $\left(F_{3,33}=23.94 ; \mathrm{p}<0.0001\right)$, but there was no significant difference in survival among the taxa $\left(F_{2,35}=0.95 ; \mathrm{p}=0.40\right.$; Fig. 3$)$. The total number of corals settled between the hybrid and the parental species also did not differ (ANOVA

Table 3. Acropora palmata, A. cervicornis, and hybrid. Kruskal-Wallis ANOVA by ranks to examine severity of afflictions across taxa. Bold p-value: statistically significant $(p<0.05)$ differences among taxa

\begin{tabular}{|lrrr|}
\hline Source & df & \multicolumn{1}{c|}{$\chi^{2}$} & \multicolumn{1}{c|}{$\mathrm{p}$} \\
\hline Disease & 2 & 29.27 & $<\mathbf{0 . 0 0 0 1}$ \\
Predation & 2 & 9.37 & $\mathbf{0 . 0 0 9 2}$ \\
Coral bleaching & 2 & 2.94 & 0.2298 \\
Parasitism & 2 & 147.83 & $<\mathbf{0 . 0 0 0 1}$ \\
Competition & 2 & 44.90 & $<\mathbf{0 . 0 0 0 1}$ \\
\hline
\end{tabular}

p > 0.05), but Acropora palmata had significantly higher settlement than A. cervicornis (Tukey's HSD, least square means $4.56,3.17,1.61, A$. palmata, hybrid, and A. cervicornis, respectively). Significantly higher settlement occurred on the tiles conditioned in the parental zone compared to the hybrid zone (Table 4, Fig. 4). The interaction term between the zone in which the tile was conditioned and taxon was not significant $(p=0.78)$ and therefore was eliminated from the model.

The percent cover and species of CCA on tiles differed between the 2 zones in which they were conditioned. Tiles conditioned in the hybrid zone were predominantly covered with Neogoniolithon spp. and had some Neophyllum spp. and Peyssonnelia spp., while tiles from the parental zone had mostly Peyssonnelia spp., and some Hydrolithon boergesenii, Paragoniolithon solubile, and Porolithon pachydermum, and a small amount of Titanoderma prototypum (R. Steneck \& S. Arnold pers. comm.). The proportion of the tile covered with CCA was quantified for a subset of tiles and was significantly greater $(t$-test; $\mathrm{p}>0.05)$ on tiles conditioned in the hybrid zone (mean 0.33 ) compared to tiles from the parental zone (mean 0.21). However, using CCA as a covariate to explain settle-

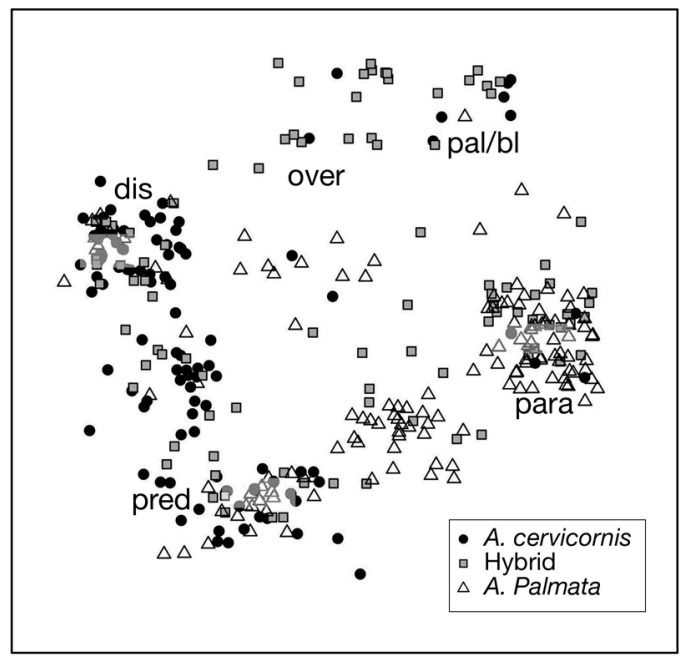

Fig. 2. Acropora palmata, A. cervicornis, and hybrid. Multidimensional scaling plot examining the patterns in affliction severity across taxa. Overgrowth = over; disease $=$ dis; paling or bleaching $=\mathrm{pal} / \mathrm{bl}_{i}$ predation $=$ pred $;$ parasitism $=$ para 


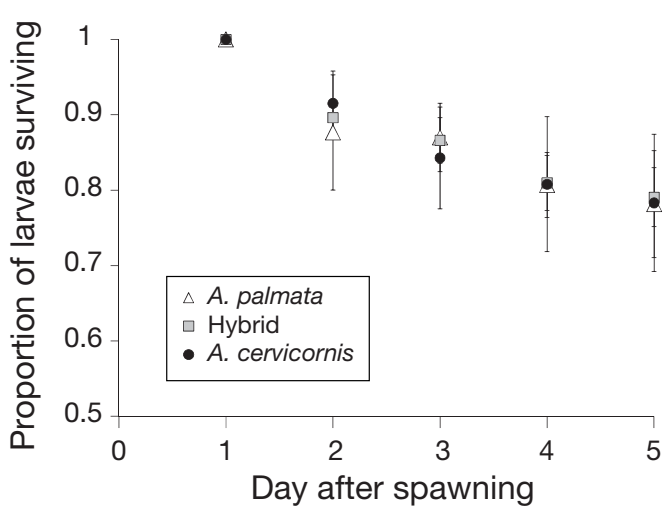

Fig. 3. Acropora palmata, A. cervicornis, and F1 hybrid. Comparison of larval survival in Caribbean acroporids during the planktonic period until competency. Means $\pm \mathrm{SE}$

ment patterns on this subset of tiles did not yield a significant result (Table 4).

\section{Post-settlement survival}

Overall survival in the parental and hybrid habitats was low after 6 wk, and no corals survived 1 yr. Only 18 of the 66 coral recruits that were deployed in cages in the parental zone survived the 6 wk period, and there was no significant difference in the number of surviving recruits among taxa in this habitat ( $\mathrm{MS}=0.02, \mathrm{df}=2, F=0.29 ; \mathrm{p}=0.75$ ). The proportion (mean $\pm \mathrm{SE}$ ) of recruits surviving 6 wk was $0.24 \pm$ $0.06,0.34 \pm 0.14$, and $0.21 \pm 0.11$ for Acropora palmata, the hybrid, and A. cervicornis, respectively. The location where tiles were conditioned (i.e. parental vs. hybrid zone) did not affect the proportion of hybrid recruits surviving $6 \mathrm{wk}(t$-test, $\mathrm{p}>0.05)$. Three of the 9 hybrid recruits that were deployed in the hybrid zone survived the $6 \mathrm{wk}$ period.

\section{Reciprocal transplants}

In March of 2007, 3 d prior to the 6 mo assessment, a severe storm damaged many acroporid colonies, broke several fragments in the reciprocal transplant experiment (Fig. 5), and flipped over 2 of the 3 bins in the intermediate depth zone. Although fragments survived, the intermediate zone bins were excluded from the growth measures because this breakage arose from bin instability rather than natural breakage. Missing transplants, i.e. no live tissue was still visible in PVC, were combined with the dead category. It is impossible to know if these small fragments
$(<10 \mathrm{~cm})$ survived after breaking off from the experimental units. Since previous research demonstrated that Acropora cervicornis fragments of this size $(<10 \mathrm{~cm})$ are rarely found in a population (Tunnicliffe 1981, 1983), it seems unlikely they would reattach and survive in this high wave energy environment.

Statistical differences between the depths was not possible because the low replication violated assumptions for chi-squared tests (i.e. no more than $20 \%$ of the expected values can be $<5$ and no value can be 0). After $23 \mathrm{mo}$, no transplants were alive at the shallow depth and only hybrids were alive at the intermediate depth (Fig. 5). When transplants were pooled across depths, statistical differences in transplant survival among taxa were found. A significant difference across time $\left(\chi^{2}=52.96, \mathrm{df}=3, \mathrm{p}<0.0001\right)$ and across taxa $\left(\chi^{2}=20.82, \mathrm{df}=2, \mathrm{p}<0.0001\right)$ was

Table 4. Acropora palmata, A. cervicornis, and F1 hybrid. Two-way ANOVA exploring differences in settlement among taxa and zone in which the tile was conditioned. A 2-way ANCOVA examining settlement on a subset of tiles where the amount of crustose coralline algae (CCA) was used as a covariate and the zone in which the tiles were conditioned and taxa as the main effects

\begin{tabular}{|c|c|c|c|c|}
\hline $\begin{array}{l}\text { Experiment } \\
\text { Source }\end{array}$ & df & $\begin{array}{l}\text { Mean } \\
\text { square }\end{array}$ & $F$ & $\mathrm{p}$-value \\
\hline \multicolumn{5}{|c|}{ Substrate preference } \\
\hline Taxa & 2 & 78.11 & 7.67 & 0.001 \\
\hline $\begin{array}{l}\text { Zone where tiles } \\
\text { were conditioned }\end{array}$ & 1 & 66.67 & 13.09 & 0.0007 \\
\hline \multicolumn{5}{|l|}{ CCA coverage } \\
\hline Taxa & 2 & 26.31 & 6.09 & 0.004 \\
\hline $\begin{array}{l}\text { Zone where tiles } \\
\text { were conditioned }\end{array}$ & 1 & 9.67 & 4.48 & 0.038 \\
\hline CCA & 1 & 4.58 & 2.12 & 0.150 \\
\hline
\end{tabular}

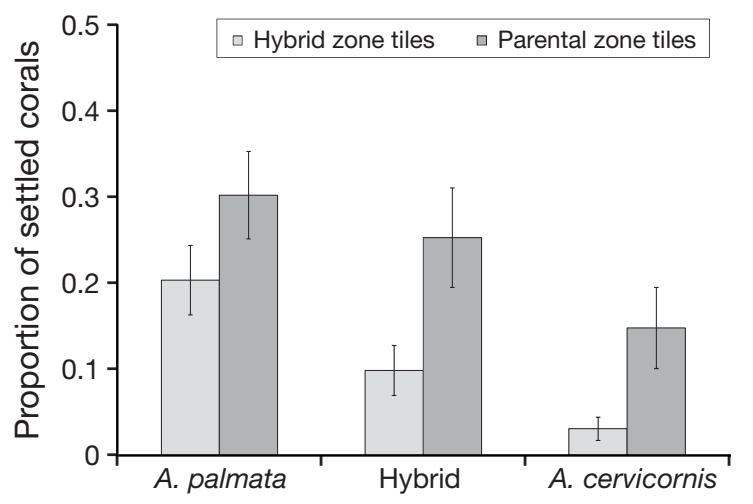

Fig. 4. Acropora palmata, A. cervicornis, and F1 hybrid. Number of settled corals on tiles conditioned in the hybrid zone $(0.75 \mathrm{~m})$ or parental species zone $(3 \mathrm{~m})$. Means $\pm \mathrm{SE}$ 


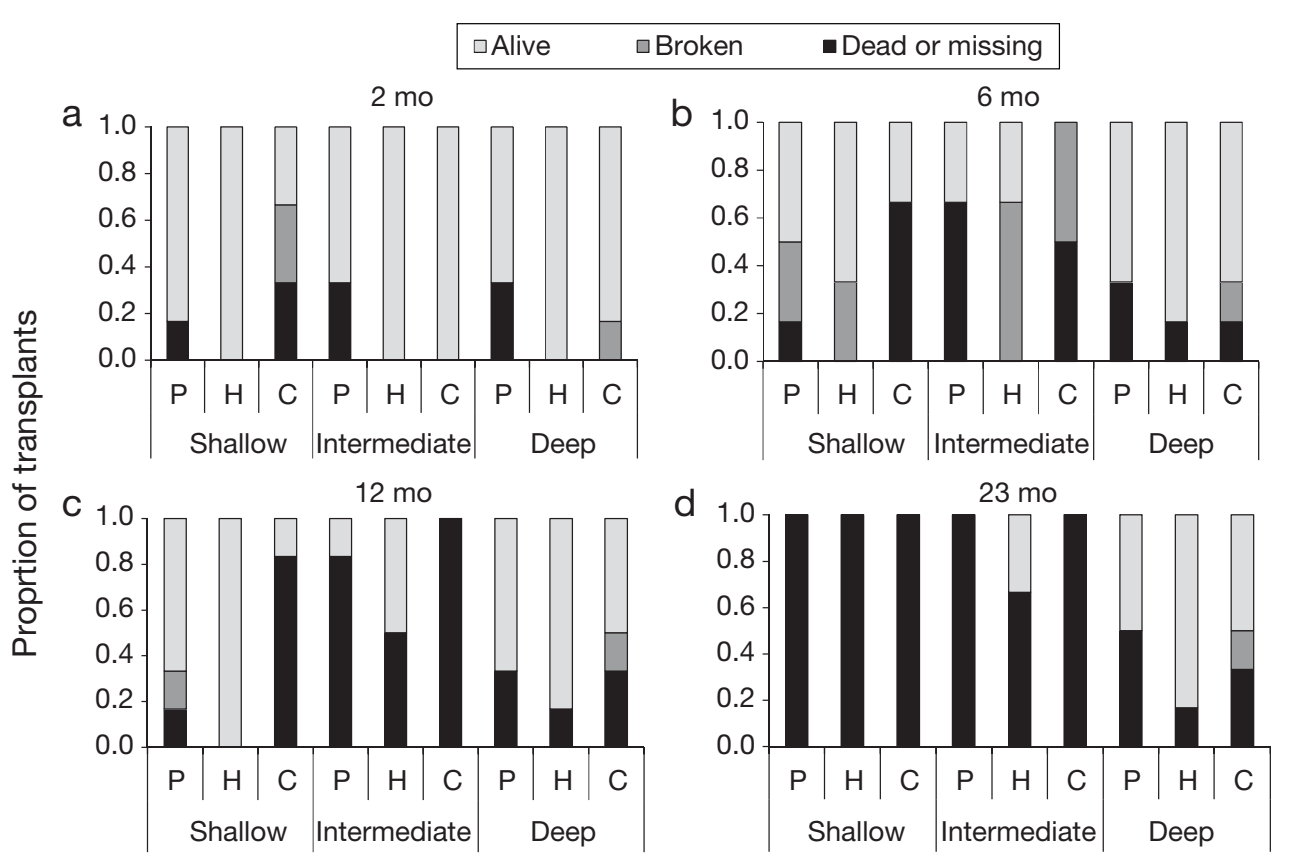

Fig. 5. Acropora palmata, A. cervicornis, and hybrid. The proportion of colonies alive, broken, and dead at (a) 2 mo, (b) $6 \mathrm{mo}$, (c) $12 \mathrm{mo}$, and (d) $23 \mathrm{mo} . \mathrm{P}=$ A. palmata; $\mathrm{H}=$ hybrid; $\mathrm{C}=$ A. cervicornis

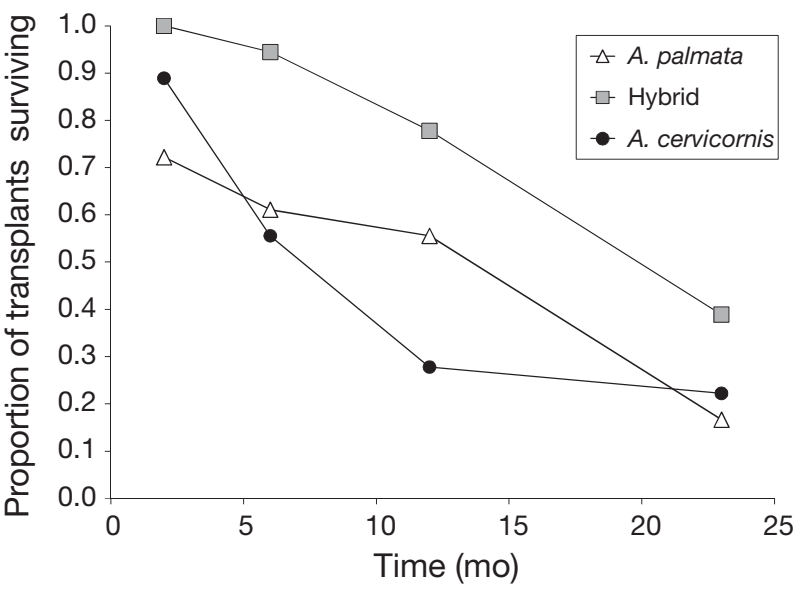

Fig. 6. Acropora palmata, A. cervicornis, and hybrid. Proportion of transplants (including broken colonies) surviving over time

observed, with hybrids having the highest overall survival (Fig. 6).

The species identity and depth at which the transplants were placed had an effect on growth rates. The interaction between habitat (shallow vs. depth) and species was not significant $(\mathrm{p}=0.09)$ and was therefore excluded from the model. Overall, growth rates for the deep habitat (mean $=46.2 \mathrm{~mm}$ ) were significantly greater than for the shallow (mean $=$ $7.8 \mathrm{~mm}$ ) (ANOVA: $\mathrm{df}=1, F=4.87, \mathrm{p}=0.04 ;$ Fig. 7 ).

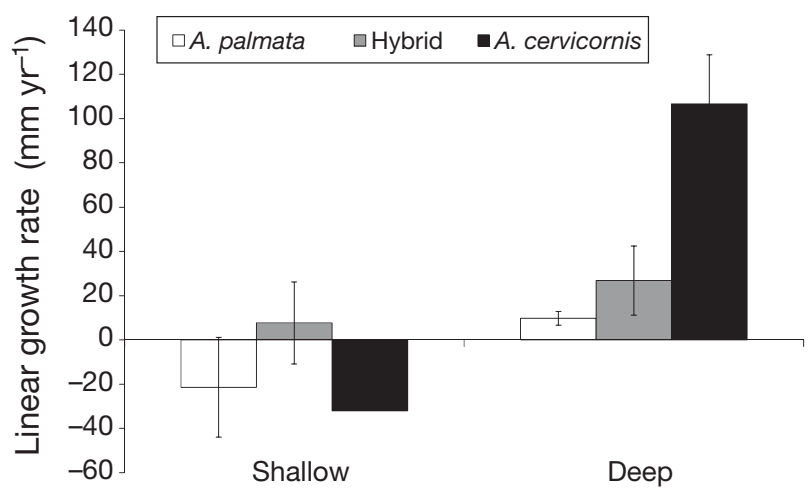

Fig. 7. Acropora palmata, A. cervicornis, and hybrid. Linear extension (mm) of transplants after $12 \mathrm{mo}$ at shallow and deep habitats. Means $\pm \mathrm{SE}$

Growth rates were also significantly different among the 3 taxa (ANOVA: $\mathrm{df}=2, F=4.01, \mathrm{p}=$ 0.03; Fig. 7). Many colonies were broken in the shallow habitat; therefore, the mean growth rate for Acropora palmata and the growth rate for the one surviving A. cervicornis transplant were negative. Hybrids, which typically live in this habitat, had a positive mean growth rate. Although hybrid and $A$. palmata transplants survived in the deeper habitat, their growth rates were significantly lower than for A. cervicornis (ANOVA: $\mathrm{df}=2, F=10.1, \mathrm{p}=0.004$; Tukey's HSD, $\mathrm{p}<0.05)$. 


\section{DISCUSSION}

Recent evidence of changes in relative hybrid abundance, variable rates of introgression across loci and sites, and hybrid expansion into the parental habitats suggests that acroporid hybrid dynamics may be changing in the Caribbean. This study confirms anecdotal evidence that hybrid densities are equivalent or greater than one or both of the parental species at some sites. Hypotheses that may explain why this change in hybrid abundance and distribution include: hybrid embryo formation has increased, asexual fragmentation has increased, or hybrid viability is higher leading to lower mortality rates. Because of the lack of ecological data on the hybrid, these hypotheses are difficult to test but this study examining the strength of postzygotic barriers, combined with prezygotic and genotypic data from other studies, may reveal their potential.

Although molecular analysis was not performed to determine the generation of hybrids assessed in this study, the conclusion remains the same: hybrids are not inferior to the parental species at any examined life history stage. This suggests that the postzygotic barrier of hybrid inviability likely is not acting in this system. If this study had found reduced hybrid viability, then it would be difficult to determine which postzygotic mechanism (postzygotic hybrid inviability or hybrid breakdown) was responsible for the lowered viability. Since molecular analysis was not conducted to determine the hybrid generation, hybrid breakdown cannot be ruled out as a potential postzygotic mechanism. However, in light of recent evidence of extensive introgression at some sites and the high hybrid viability found in this study, it seems unlikely that hybrid breakdown is an effective postzygotic barrier.

\section{Intrinsic postzygotic hybrid inviability}

The afflictions that affect the adults vary across sites and across taxa, but little temporal variation exists with the exception of parasitism in Acropora palmata and the hybrid and disease in A. cervicornis. Disease is documented as the main contributor to the decline in A. palmata and A. cervicornis (Aronson \& Precht 2001, Bruckner 2002, Precht et al. 2002), but hybrids have equivalent or lower incidence of disease compared to A. palmata and A. cervicornis, respectively. Predators such as fish, corallivorous snails, and fireworms, also cause con- siderable mortality in the parental species, yet hybrids have lower incidence of predation than both parental species. Acropora palmata colonies have the highest incidence of parasitism, likely because of the large surface area of their branching morphology. Likewise, hybrids had intermediate branching morphology and intermediate levels of parasitism. Overgrowth by other organisms is higher in hybrids than in parental species. With the exception of a few incidences of interactions with sponges, acroporid tissue is almost exclusively overgrown by macroalgae. The hybrids' tightly clumped branching morphology is likely what makes it particularly vulnerable to macroalgal overgrowth. Often, macroalgae grow among the branches at the base of the hybrid. The fitness consequences of macroalgal overgrowth on the acroporid hybrid are not known. The coral tissue at the base of these colonies, when covered with macroalgae, was dead; however, the majority of the tissue of the colony was not in contact with macroalgae and appeared healthy (N. D. Fogarty pers. obs.).

Hybrids often live in very shallow habitats $(<1 \mathrm{~m})$ but are no more susceptible to paling or bleaching than the parental species. Only $2 \%$ of the hybrid colonies surveyed were pale and only 3 colonies were completely bleached. Acroporid hybrids are exposed to extreme temperature fluctuations and high ultraviolet radiation in the shallow habitat in which they live; therefore, it is surprising that they do not have a higher incidence of paling and bleaching, particularly since these assessments were conducted during the peak bleaching months (i.e. July to October) when sea surface temperatures are highest (McWilliams et al. 2005). This is interesting because acroporids are typically known for their high sensitivity to increased sea temperatures (Loya et al. 2001). Recent evidence demonstrates that Indo-Pacific acroporid corals are particularly metabolically dependent on zooxanthellae, but can synthesize photoprotective compounds to prevent damage from high solar radiation (Shinzato et al. 2011). It appears that Caribbean acroporid hybrids have adapted to withstand high temperature and UV irradiance associated with extremely shallow environments. As sea temperatures rise, it is likely that the hybrid will be more tolerant than the parental species.

No significant difference in survival was seen between the hybrid and the parental species during the earliest life history stages (i.e. larval and postsettlement survival). Settlement was low overall (i.e. mean of $35 \%$ per trial), but highest in Acropora palmata, followed by the hybrid and A. cervicornis. 
Previous studies documented much higher settlement rates for the parental species, but lower postsettlement survival after $6 \mathrm{wk}$ (Ritson-Williams et al. 2010). Ritson-Williams et al. (2010) examined postsettlement survival on 2 different CCA species in Belize. Mean survival rates of A. palmata on Hydrolithon boergesenii and Titanoderma prototypum was $16 \%$ and $19 \%$, respectively, and A. cervicornis had survival rates of $13 \%$ on $T$. prototypum, but no survivors were found on $H$. boergesenii. In this study, postsettlement survival at 6 wk averaged $24 \%$ for $A$. palmata, $35 \%$ in the hybrid, and $21 \%$ for A. cervicornis. Although the mean hybrid postsettlement survival was higher, it was not significantly different from the parental species, possibly as a result of low sample size. After $1 \mathrm{yr}$, all acroporid recruits had died. The overall high postsettlement mortality is consistent with the limited number of naturally occurring acroporid sexual recruits seen across the Caribbean (Tunnicliffe 1981, Knowlton et al. 1990, Bruckner 2002, Precht et al. 2004).

\section{Extrinsic postzygotic ecological inviability}

Larval substrate selection is a critical stage for sessile organisms because this decision dictates the habitat in which they will live for the rest of their life. In Belize, larvae from each acroporid taxon were given the option of settling on substrates conditioned in the hybrid or in the parental zone. Despite often inhabiting extremely shallow habitats, hybrids, like the parental species, prefer substrates that had been conditioned in the deeper parental habitat. One explanation as to why hybrids are typically found in a zone in which they do not prefer, is that hybrids settle on the edge of the parental zone and get dispersed to the shallows during storms. Because hybrids can survive well and grow quickly in shallow environments, they are likely able to attach and persist with little competition from other coral species. Alternatively, hybrid preference for the parental zone is not absolute; perhaps the hybrids that persist in the shallows are those few individuals that originally settled there. These hypotheses do not offer an explanation as to why all acroporids have a preference to the tiles conditioned in the deeper habitat. It is possible that the substrate conditioned in the parental zone is more attractable.

Previous studies suggest coral larvae are attracted to CCA (Carlon \& Olson 1993, Morse et al. 1988, 1994, Morse \& Morse 1991, Heyward \& Negri 1999, Golbuu \& Richmond 2007, Ritson-Williams et al.
2010). Here, there was less settlement on the tiles with more CCA and using the proportion of CCA covering the tiles as a covariate did not explain patterns of settlement. Since it appears that the quantity of CCA does not explain the settlement preference for the parental zone, perhaps the CCA identity or the bacterial community does. RitsonWilliams et al. (2010) found that some CCA species (i.e. Hydrolithon boergesenii and Titanoderma prototypum) facilitate Acropora cervicornis and A. palmata settlement. They found less settlement on Porolithon pachydermum and Paragoniolithon solubile, but settlement was seen on the bare rock substrate adjacent to these species of CCA. Consequently, acroporid larvae in this study may be attracted to tiles in the parental zone because they hosted CCA (i.e. H. boergesenii and T. prototypum) known to facilitate acroporid settlement (RitsonWilliams et al. 2010). An alternative explanation is that the larvae are attracted to the biofilm associated with the parental zone instead of the CCA, but the microbes associated with the biofilm of these tiles were not examined.

In Curacao, hybrid fragments in the reciprocal transplant experiment had greater survival than the parental species. In March, just prior to the 6 mo assessment, an intensive storm damaged Acropora palmata colonies. Many A. palmata and A. cervicornis transplants in the shallow and intermediate zone either died or broke at the base with no live tissue remaining. Although there were many hybrid transplants that were broken after this disturbance, at least some of the hybrid colony was still intact, and no mortality was seen in the shallow and intermediate depths. This suggests that the morphology and skeletal structure of the hybrid is resistant to severe damage that causes mortality during storms. Acropora cervicornis, however, suffered high mortality in the shallows, likely from its arborescent morphology that makes it susceptible to breakage. Hybrid vigor is suggested when hybrids survive and grow well in habitats other than the habitat in which they are typically found (Wang et al. 1997). After $1 \mathrm{yr}$, hybrid survival in each zone was higher than for either parental species. After nearly 2 yr, no acroporid transplant survived the shallow zone, and hybrids had higher survival in the intermediate and deep zones than the parental species. Because hybrids typically live at shallow depths but seem to prefer intermediate depths and survive well at deeper depths, it appears that exogenous selection or ecological inviability is not occurring in Caribbean acroporid hybrids. 


\section{CONCLUSIONS}

Based on the biological species concept, since prezygotic barriers in Caribbean acroporids are weak (Fogarty et al. in press), postzygotic barriers are expected to be strong in order to prevent the introgression of genes between the parental species (Coyne \& Orr 2004). This study found no evidence that putative F1 hybrids were inferior to the parental species at any examined life history stage and that hybrid density is often equivalent or greater than the parental species. These findings of high hybrid viability lend support to the hypothesis that the high hybrid density is a result of hybrids suffering less mortality in recent decades. Yet, in light of other research, the story may be more complex. If these hybrids were relics of rare hybridization events that have survived disease outbreaks, they would likely be large and contribute most of the acroporid biomass. Additionally, the genotypic diversity of hybrid populations should be low because only a few genotypes exist. This study found that hybrid biomass was often lower than that of the parental species. Understandably, because of constraints in their morphology, hybrids and A. cervicornis may never reach the same biomass as $A$. palmata; however, hybrids were significantly smaller than A. cervicornis at 4 of 6 sites. The relatively small hybrid size can likely be attributed to fragmentation in the shallow, high wave energy environment they often inhabit. If the hybrids' size and abundance are a result of fragmentation of rare relic hybrid colonies, then hybrid genotypic diversity would be low because most colonies would share the same genotype. A molecular study examining the genotypic diversity of hybrids across the Caribbean found that hybrid genotypic diversity was variable. In fact, most of the sampled hybrids were unique genotypes suggesting that asexual fragmentation cannot explain high hybrid abundance or small hybrid size (Fogarty 2010). This provides evidence that present day hybrid colonies are not likely from past relics or from increased asexual propagation. The remaining hypothesis of how Caribbean acroporid corals maintained the species integrity for millions of years is that reproductive isolation is density dependent (Fogarty et al. in press). When the parental species were at high densities, eggs were swamped by conspecific sperm and hybridization was infrequent. In the past $30 \mathrm{yr}$ the parental species' densities have been drastically reduced (Bruckner 2002, Precht et al. 2002). Prior to the decline of the parental species, conspecific sperm likely immediately inundated conspecific eggs. Now with lower sperm concentrations, acroporid eggs likely float unfertilized, increasing encounters with heterospecific sperm and the probability of hybridization (Fogarty et al. in press).

If density-dependent reproductive isolation is occurring in Caribbean acroporids, and first generation hybridization is increasing at some sites, then why does previous molecular data lack evidence of F2 hybrids (Vollmer \& Palumbi 2002)? One possibility is that the limited sample size $(\mathrm{n}=22$ and 28 for minicollagen and calmodulin genes, respectively) and few geographic sites $(n=3)$ prevented the detection of later generation hybrids. A more extensive sampling effort across a wider geographic area will likely reveal later generation hybrids. If hybridization is increasing, then introgression will likely also occur at higher frequencies. On an evolutionary time-scale, Acropora cervicornis' genome may be at risk of genetic swamping, but in the short term, viable hybrids can provide complex habitat to numerous marine organisms in reef environments typically not inhabitable by other hermatypic coral species.

Acknowledgements. I thank D. Levitan, A. Winn, J. Travis, J. Wulff, C. ter Horst, M. Adreani, K. Lotterhos, A. PlataStapper, M. Lowenberg, and the anonymous reviewers for the helpful comments on the manuscript. A special thank you to V. Paul, R. Ritson-Williams, K. Morrow, B. Biggs, C. ter Horst, S. Arnold, W. Cooper, K. DeFosset, B. Fogarty, J. Nolan, E. McRay, and L. Huebner for their field assistance, R. Ritson-Williams and K. Morrow for their efforts examining tiles for postsettlement survival, K. Lotterhos for her help with the MDS, and L. Rubio for her assistance with analyzing digital photographs. This research was made possible by the National Geographic Society (8230-07), the Caribbean Coral Reef Ecosystems (CCRE) program (contribution no. 914) and the Smithsonian Marine Science Network, the PADI foundation, the American Academy of Underwater Science (AAUS), the Project AWARE foundation, LernerGray Memorial Fund of the American Museum of Natural History, and FSU's International dissertation, Bennison, Gramling, and Short Fellowships.

\section{LITERATURE CITED}

Acropora Biological Review Team (2005) Atlantic Acropora status review document. Report to National Marine Fisheries Service, Southeast Regional Office. Available at http://sero.nmfs.noaa.gov/pr/pdf/050303\%20status\% 20review.pdf

Adey WW, Gladfelter W, Ogden J, Dill R (1977) Field guidebook to the reefs and reef communities of St. Croix, Virgin Islands. Third International Coral Reef Symposium. The Atlantic Reef Committee, Miami, Florida

Anderson E (1949) Introgressive hybridization. Wiley, New York

Arnold ML (1997) Natural hybridization and evolution. Oxford University Press, Oxford 
Arnold ML (2006) Evolution through genetic exchange. Oxford University Press, Oxford

- Arnold ML, Fogarty ND (2009) Reticulate evolution and marine organisms: the final frontier? Int J Mol Sci 10: 3836-3860

Aronson RB, Precht WF (2001) White-band disease the changing face of Caribbean coral reefs. Hydrobiologia 460:25-38

Baird AH, Morse ANC (2004) Induction of metamorphosis in larvae of the brooding corals Acropora palifera and Stylophora pistillata. Mar Freshw Res 55:469-472

Brown BE (1997) Coral bleaching: causes and consequences. Coral Reefs 16:S129-S138

Bruckner AW (2002) Potential application of the U.S. Endangered Species Act as a conservation strategy. Proceedings of the Caribbean Acropora Workshop. NOAA Technical Memorandum, NMFS-OPR-24, Silver Springs, MD

Budd AF, Johnson KG (1999) Origination preceding extinction during late Cenozoic turnover of Caribbean reef. Paleobiology 25:188-200

Budd AF, Stemann TA, Johnson KG (1994) Stratigraphic distributions of genera and species of neogene to recent Caribbean reef corals. J Paleontol 68:951-977

Cairns SD (1982) Stony Corals (Cnidaria; Hydrozoa, Scleractinia) of Carrie Bow Cay, Belize. Smithson Contrib Mar Sci 12:272-302

> Carlon DB, Olson RR (1993) Larval dispersal distance as an explanation for adult spatial pattern in two Caribbean reef corals. J Exp Mar Biol Ecol 173:247-263

Cortes J (2003) Latin American coral reefs. Elsevier Science, Amsterdam

Coyne JA, Orr HA (2004) Speciation. Sinauer Associates, Sunderland, MA

Crow JF (1948) Alternative hypothesis to hybrid vigor. Genetics 43:477-487

> Dobzhansky T (1937) Genetic nature of species differences. Am Nat 71:404-420

Dobzhansky T (1970) Genetics of the Evolutionary Process. Columbia University Press, New York

> Dowling TE, Secor CL (1997) The role of hybridization and introgression in the diversification of animals. Annu Rev Ecol Syst 28:593-619

Fogarty ND (2010) Reproductive isolation and hybridization dynamics in threatened Caribbean acroporid corals. PhD dissertation, Florida State University, Tallahassee

Fogarty ND, Vollmer SV, Levitan DR (in press) Weak prezygotic isolating mechanisms in threatened Caribbean Acropora corals. PloS One

Glynn PW (1993) Coral reef bleaching: ecological perspectives. Coral Reefs 12:1-17

> Golbuu Y, Richmond RH (2007) Substratum preferences in planula larvae of two species of scleractinian corals Goniastrea retiformis and Stylaraea punctata. Mar Biol 152:639-644

Goreau TF (1959) The ecology of Jamaican coral reefs I. Species composition and zonation. Ecology 40:67-90

Goreau TJ, McClanahan T, Hayes R, Strong A (2000) Conservation of coral reefs after the 1998 global bleaching event. Conserv Biol 14:5-15

Grant PR (ed) (1981) Plant speciation. Columbia University Press, New York

Harrigan JF (1972) The planulae larva of Pocillopora damicornis. Lunar periodicity of swarming and substratum selection behavior. PhD dissertation, University of Hawaii
Hatta M, Fukami H, Wang W, Omori M and others (1999) Reproductive and genetic evidence for a reticulate evolutionary history of mass-spawning corals. Mol Biol Evol 16:1607-1613

> Hemond EM, Vollmer SV (2010) Genetic diversity and connectivity in the threatened staghorn coral (Acropora cervicornis) in Florida. PLoS ONE 5:e8652

- Heyward AJ, Negri AP (1999) Natural inducers for coral larval metamorphosis. Coral Reefs 18:273-279

Hogarth WT (2006) Endangered threatened species: final listing determinations for the elkhorn and staghorn coral. Fed Regist 71:26852-26861

Knowlton N, Lang JC, Keller BD (1990) Case study of natural population collapse: post-hurricane predation on Jamaican staghorn corals. Smithson Contrib Mar Sci 31: $1-25$

Lamarck JP (1816) Histoire naturelle des animaux sans vertebres, Vol 2. Verdiere, Paris

Lang JC, Alcolando P, Carricart-Ganivet JP, Chippone M and others (1998) Status of coral reefs in the northern areas of world. Australian Institute of Marine Science, Townsville

Levin DA, Schmidt KP (1985) Dynamics of a hybrid zone in Plox: an experimental demographic investigation. Am J Bot 72:1404-1409

Levin DA, Francisco-Ortega J, Jansen RK (1996) Hybridization and the extinction of rare plant species. Conserv Biol 10:10-16

Levitan DR, Sewell MA, Chia FS (1992) How distribution and abundance influence fertilization success in the sea urchin Strongylocentrotus fransciscanus. Ecology 73: 248-254

- Loya Y, Sakai K, Yamamoto K, Sambali H, Van Woesik R (2001) Coral bleaching: the winners and losers. Ecol Lett $4: 122-131$

Mayr E (1963) Animal species and evolution. Belknap Press, Cambridge

McNeill DF, Budd AF, Borne PF (1997) Earlier (late Pliocene) first appearance of the Caribbean reef-building coral Acropora palmata: stratigraphic and evolutionary implications. Geology 25:891-894

McWilliams JP, Cote IM, Gill JA, Sutherland WJ, Watkinson AR (2005) Accelerating impacts of temperatureinduced coral bleaching in the Caribbean. Ecology 86: 2055-2060

Mendelson TC, Imhoff VE, Venditti JJ (2007) The accumulation of reproductive barriers during speciation: postmating barriers in two behaviorally isolated species of darters (Percidae: Etheostoma). Evolution 61:2596-2606

Miller MW, Bourque AS, Bohnsack JA (2002) An analysis of the loss of acroporid corals at Looe Key, Florida, USA: 1983-2000. Coral Reefs 21:179-182

Morse DE, Morse A (1991) Enzymatic characterization of the morphogen recognized by Agaricia humilis (scleractinian coral) larvae. Biol Bull 181:104-122

> Morse DE, Hooker N, Morse ANC, Jensen RA (1988) Control of larval metamorphosis recruitment in sympatric agariciid corals. J Exp Mar Biol Ecol 116:193-217

- Morse D, Morse A, Raimondi P, Hooker N (1994) Morphogen-based chemical flypaper for Agaricia humilis coral larvae. Biol Bull 186:172-181

Odorico DM, Miller DJ (1997) Variation in the ribosomal internal transcribed spacers and 5.8S rDNA among five species of Acropora (Cnidaria; Scleractinia): patterns of variation consistent with reticulate evolution. Mol Biol 
Evol 14:465-473

Patterson KL, Porter JW, Richie KB, Polson SW and others (2002) The etiology of white pox, a lethal disease of the Caribbean elkhorn coral Acropora palmata. Proc Natl Acad Sci USA 99:8725-8730

Precht WF, Bruckner AW, Aronson RB, Bruckner RJ (2002) Endangered acroporid corals of the Caribbean. Coral Reefs 21:41-42

Precht WF, Robbart ML, Aronson RB (2004) The potential listing of Acropora species under the US Endangered Species Act. Mar Pollut Bull 49:534-536

Ramsey J, Bradshaw HD, Schemske DW (2003) Components of reproductive isolation between the monkeyflowers Mimulus lewissi and M. cardinalis (Phymaceae). Evolution 57:1520-1534

Rhymer JM, Simberloff D (1996) Extinction by hybridization and introgression. Annu Rev Ecol Syst 27:83-105

Rieseberg LH (1997) Hybrid origins of plant species. Annu Rev Ecol Syst 28:359-389

Risk JM, Sammarco WP, Dinger NE (1995) Bioerosion in Acropora across the continental shelf of the Great Barrier Reef. Coral Reefs 14:79-86

Ritson-Williams R, Arnold SN, Fogarty ND, Steneck RS, Vermeij MJA, Paul VJ (2009) New perspectives on ecological mechanisms affecting coral recruitment on reef. Smithson Contrib Mar Sci 38:437-457

Ritson-Williams R, Paul VJ, Arnold SN, Steneck RS (2010) Larval settlement preferences and post-settlement survival of the threatened Caribbean corals Acropora palmata and A. cervicornis. Coral Reefs 29:71-81

Rutzler K, MacIntyre IG (1982) Habitat distribution and community structure of the barrier reef complex at Carrie Bow Cay, Belize. I. Structure and communities. Smithsonian Institute Press, Washington, DC

Rylaarsdam KW (1983) Life histories and abundance patterns of colonial corals on Jamaican reefs. Mar Ecol Prog Ser 13:249-260

Sammarco PW (1982) Polyp bail-out: an escape response to environmental stress and new means of reproduction in corals. Mar Ecol Prog Ser 10:57-65

Shinzato C, Shoguchi E, Kawashima T, Hamada M and others (2011) Using Acropora digitifera genome to understand coral responses to environmental change. Nature 476:320-323

Stebbins GLJ (1959) The role of hybridization in evolution. Proc Am Philos Soc 103:231-251

Szmant AM (1986) Reproductive ecology of Caribbean reef corals. Coral Reefs 5:43-53

Szmant AM, Gassman NJ (1990) The effects of prolonged 'bleaching' on the tissue biomass and reproduction of the reef coral Montastrea annularis. Coral Reefs 8:217-224

Tudhope AW, Allison N, Le Tissier MDA, Scoffin TP (1992) Growth characteristics and susceptibility to bleaching in massive Porites corals, South Thailand. Proc 7th Int Coral Reef Symp, Guam 1:64-69

Editorial responsibility: Matthias Seaman,

Oldendorf/Luhe, Germany
Tunnicliffe V (1981) Breakage and propagation of the stony coral Acropora cervicornis. Proc Natl Acad Sci USA 78: $2427-2431$

Tunnicliffe V (1983) Caribbean staghorn coral populations: pre-hurricane Allen conditions in Discovery Bay, Jamaica. Bull Mar Sci 33:132-151

van Oppen MJH, Willis BL, Van Vugt HWJA, Miller DJ (2000) Examination of species boundaries in the Acropora cervicornis group (Scleractinia, Cnidaria) using nuclear DNA sequence analyses. Mol Ecol 9:1363-1373

Vargas-Angel B, Thomas JD, Hoke SM (2003) High-latitude Acropora cervicornis thickets off Fort Lauderdale, Florida, USA. Coral Reefs 22:465-473

> Vermeij MJA, Sandin SA (2008) Density-dependent settlement and mortality structure the earliest life phases of a coral population. Ecology 89:1994-2004

Veron JEN (1995) Corals in space and time: the biogeography and evolution of the Scleractinia. Cornell University Press, Ithaca, NY

> Vollmer SV, Palumbi SR (2002) Hybridization and the evolution of reef coral diversity. Science 296:2023-2025

- Vollmer SV, Palumbi SR (2007) Restricted gene flow in the Caribbean staghorn coral Acropora cervicornis: implications for the recovery of endangered reefs. J Hered 98: $40-50$

> Wallace CC (1985) Reproduction, recruitment and fragmentation in nine sympatric species of the coral genus Acropora. Mar Biol 88:217-234

Wallace CC (1999) Staghorn corals of the world: a revision of the genus Acropora. CSIRO Publishing, Collingwood, VIC

> Wang H, McArthur ED, Sanderson SC, Graham JH, Freeman DC (1997) Narrow hybrid zone between two subspecies of big sagebrush (Artemisia tridentata: Asteraceae). IV. Reciprocal transplant experiments. Evolution 51:95-102

Webster NS, Smith LD, Heyward AJ, Watts JEM, Webb RI, Blackall LL, Negri AP (2004) Metamorphosis of a scleractinian coral in response to microbial biofilms. Appl Environ Microbiol 70:1213-1221

Wheaton T, Callahan M, Brooks S, Beaver C and others (2010) Dry Tortugas National Park (DRTO) long term monitoring and assessment project: annual report 2005-2006. Fish and Wildlife Research Institute, St. Petersburg, FL

Wilkinson C (2000) Status of coral reefs of the world: 2000. Australian Institute of Marine Science, Cape Ferguson

> Williams DE, Miller MW (2005) Coral disease outbreak: pattern, prevalence and transmission in Acropora cervicornis. Mar Ecol Prog Ser 301:119-128

Williams DE, Miller MW, Kramer KL (2006) Demographic monitoring protocols for threatened Caribbean Acropora spp. corals. NOAA Tech Memo NMFS-SEFSC-543, Miami, FL

Willis BL, van Oppen MJH, Miller DJ, Vollmer SV, Ayre DJ (2006) The role of hybridization in the evolution of reef corals. Annu Rev Ecol Evol Syst 37:489-517

Submitted: March 1, 2011; Accepted: October 25, 2011

Proofs received from author(s): January 23, 2012 